\title{
Mass Observation, Apathy, and Electoral Politics in England, 1937-1950
}

\author{
David Thackeray \\ Department of History, University of Exeter, Exeter, UK \\ Email: D.Thackeray@exeter.ac.uk
}

\begin{abstract}
While various historians use Mass Observation sources to study popular engagement with politics in the 1940s, they tend to rely on file reports summarizing research or the writings of the national panel, which paid limited attention to how the public engaged with key aspects of electioneering. By contrast, we re-examine Mass Observation's various election surveys to explore people's assumptions about how election campaigns should be conducted, the qualities looked for in political parties, and their reflections on the records of governments. Our conclusions shed light on the transformation of British public politics after 1918. During the interwar years it became common thinking to assume that parties would centre their campaigning around a detailed programme for government. Whereas Mass Observation's employees often claimed that much of the public was apathetic about politics, a reanalysis of the survey results indicates that many people were eager to be seen to be able to offer a considered assessment of the veracity of the competing parties' promises. Mass Observation's election studies were criticized for their supposed amateurism. However, they offer richer insights into how the public engaged with party programmes than the quantitative surveys that came to dominate election studies in the 1950 s and beyond.
\end{abstract}

In 1937, people in Bolton received an unusual addition to the standard election circulars. Three 'non-party election addresses' were distributed during that year's municipal elections, one featuring music-hall lyrics, another in the form of a comic-strip, and the last resembling a football pools coupon. Each sought to awaken the interest of the habitual non-voter. Recipients were informed that as with doing the pools, choosing who to vote for required skill and careful attention to past form: 'Are you going to let the small minority who are interested in politics decide on Monday, Nov. 1 who is going to

\footnotetext{
(C) The Author(s), 2021. Published by Cambridge University Press. This is an Open Access article, distributed under the terms of the Creative Commons Attribution-NonCommercial-NoDerivatives licence (http://creativecommons. org/licenses/by-nc-nd/4.0), which permits non-commercial re-use, distribution, and reproduction in any medium, provided that no alterations are made and the original article is properly cited. The written permission of Cambridge University Press must be obtained prior to any commercial use and/or adaptation of the article.
} 
govern - not only them but you for another three years? ${ }^{1}$ While the leaflets were printed by 'Civic Responsibilities, Manchester', their true source was Mass Observation (MO), a social-investigation organization, which had established an operation in Bolton (renamed as 'Worktown') earlier that year.

According to Tom Harrisson, the leader of the Worktown project, "the basic assumption of these experiments was that the people were not positively apathetic; that they failed to vote because the idea hadn't been sold to them'. ${ }^{2}$ The main political parties were largely to blame for this state of affairs given that most of their election literature was unappealing to the eye, and full of formulaic phrases and vague platitudes, far removed from the conventions of everyday speech. ${ }^{3}$ Harrisson's experiment appears to have been a success, raising turnout on streets where the leaflets were distributed. ${ }^{4}$

While several historians use Mass Observation as a source to explore the political culture of the 1940s, scholars have given little attention to how it can help us understand how the public engaged with campaign literature. ${ }^{5}$ This article builds on the approach developed in David Cowan's recent analysis of the reception of Labour's 'Ask your Dad' slogan in 1948-9. Cowan uses MO survey data to study how people interacted with political campaigning, considering how their responses to the slogan were shaped by concerns and mindsets inherited from earlier decades. ${ }^{6}$ Our reanalysis of Mass Observation's election survey data contributes to a growing literature which is re-examining the field notes and survey data produced by mid-twentieth-century British social science. To date, these studies have focused largely on re-reading sociologies of class, whereas this article suggests that using this approach can also be useful for understanding popular attitudes to politics. ${ }^{7}$ Our findings complement Jon Lawrence's argument that British public politics was transformed after 1918, with the decline of hitherto common forms of rowdy and sensationalist electioneering. ${ }^{8}$ Campaign literature played a central role in shaping this more

\footnotetext{
${ }^{1}$ The football pools leaflet is reprinted in Tom Harrisson, Britain revisited (London, 1961), pp. 79-82; the music lyrics leaflet survives in the Worktown Collection (hereafter WC), 11-A/10.

${ }^{2}$ Tom Harrisson undated notes [c. 1938], WC, 12-E/212.

${ }^{3}$ Ibid., 12-E/205.

${ }^{4}$ Harrisson, Britain revisited, p. 107.

${ }^{5}$ Among the key studies are Steven Fielding, "What did "the people" want?: the meaning of the 1945 General Election', Historical Journal, 35 (1992), pp. 623-39; Steven Fielding, Peter Thompson, and Nick Tiratsoo, 'England arise!' The Labour party and popular politics in 1940s Britain (Manchester, 1995); Jonathan Moss, Nick Clarke, Will Jennings, and Gerry Stoker, 'Golden age, apathy, or stealth? Democratic engagement in Britain, 1945-50', Contemporary British History, 30 (2016), pp. 441-62.

${ }^{6}$ David Cowan, 'The "progress of a slogan": youth, culture, and the shaping of everyday political languages in late 1940s Britain', Twentieth Century British History, 29 (2018), pp. 435-58.

${ }^{7}$ Key interventions include Mike Savage, 'Working class identities in post-war Britain: revisiting the affluent worker study', Sociology, 39 (2005), pp. 929-46; Selina Todd, 'Affluence, class and Crown Street: re-investigating the post-war working class', Contemporary British History, 22 (2008), pp. 50118; Jon Lawrence, Me, me, me: the search for community in post-war England (Oxford, 2019), chs. 2-5; Adrian Bingham's ongoing 'Everyday politics, ordinary lives' project is also using social survey data to re-examine the role of politics in everyday life.

${ }^{8}$ Jon Lawrence, 'The transformation of British public politics after the First World War', Past \& Present, 190 (2006), pp. 185-216, at pp. 185-6, 197-201.
} 
peaceable and supposedly rational politics. Finally, this article suggests that the 'valence model' developed by the British Election Study over the last fifty years, which stresses that voters make their judgements based on an evaluation of a party's performance rather than on class loyalties, is useful for understanding British political culture in the 1940s. ${ }^{9}$

During the interwar years, it became common thinking to assume that parties would centre their campaigning around a detailed programme for government. Manifestos and election addresses became the key means for candidates to outline the programme on which they stood. In January 1938, the Worktown team produced their first detailed analysis of a by-election at Farnworth, near Bolton. Labour held the seat following the death of the incumbent MP. During the campaign, Harrisson noted that 'first importance' was attached to the election address (the candidate's personal manifesto), a document whose significance eclipsed the well-established spectacles of the eve-of-poll meeting and the billboard poster. ${ }^{10}$ Such thinking reflected a common assumption about the post-1918 electorate: that most people were 'silent voters', who rarely attended public meetings, did not follow politics closely, and lacked longstanding party loyalties. A well-constructed election address was vital given that it was assumed that voters would make up their minds based on what they read at home. ${ }^{11}$ Or, as a draft for the unfinished MO book 'Politics and the non-voter' put it: 'The meeting is designed to interest only those sufficiently interested to listen. The leaflet is designed to interest and influence the otherwise unapproached nine-tenths of the electorate. ${ }^{12}$

Voters were encouraged to weigh up the competing claims carefully, being wary of gimmickry and loose promises, and mindful of governments' past records. The evidence collected by Mass Observation in election questionnaires suggests that many people took this ideal to heart. Few paid detailed attention to the introduction of policy initiatives outside of election campaigns, identified as partisans for a particular party, or discussed individual policies in depth when responding to questionnaires. At times, these evasions were viewed by MO's employees as signs of political apathy or disinterest. And yet, a reanalysis of the survey data indicates that many people were eager to be seen to be politically engaged and able to offer a considered assessment of the veracity of the competing parties' promises.

From 1937 onwards, Mass Observation collected thoughts on people's engagement with elections in a variety of forms including questionnaires, responses to panel directives, the writing of election diaries, interviews with candidates and agents, observations at meetings, and overheard conversations. The challenges of engaging with this broad range of evidence helps explain

\footnotetext{
${ }^{9}$ For a historical examination of the valence model, see Harold D. Clarke, David Sanders, Marianne C. Stewart, and Paul Whiteley, Political choice in Britain (Oxford, 2004).

${ }^{10}$ Tom Harrisson, 'The purpose of politics' [misc. file], WC, 12-E/228. The term 'election address' is used throughout this article to refer to the written address issued by candidates at the start of an election campaign.

${ }^{11}$ Frank Gray, Confessions of a candidate (London, 1925), p. 19; Henry Houston and Lionel Valdar, Modern electioneering practice (London, 1922), pp. 19, 21; Lawrence, 'Transformation', p. 205.

12 'Writing', WC, 6-A/123.
} 
why historians have come to such differing conclusions about what MO sources can tell us about British political culture in the 1940s.

Steven Fielding has used Mass Observation file reports, which summarized survey data with a view to later use in publications, to suggest that much of the public took little interest in politics. While Labour's promise of full employment and social security was widely popular, he argues that the public lacked enthusiasm for more radical social change. ${ }^{13}$ In an important critique of this work, James Hinton claims that Fielding and his co-authors take observations about political apathy recorded by MO staff in their file reports at face value. In doing so, they neglect to consider how people's evasiveness when questioned about their political opinions could be the result of their discomfort with party political discourses or their defence of alternative ideas. Moreover, this approach pays little sustained attention to how the apparently 'apathetic' political mood of the 1940s compared with earlier or later periods. As Hinton suggests, far from the public having little time for party politics, the 1950 and 1951 elections were characterized by high levels of turnout compared to interwar elections. ${ }^{14}$

Jonathan Moss, Nick Clarke, Will Jennings, and Gerry Stoker have since sought to gain an unmediated view of public engagement with politics by exploring the 'raw data' produced by volunteer writers for Mass Observation between 1945 and 1950. They suggest that while voting was widely seen as a key duty in a democratic society, there was widespread frustration with the 'mud slinging' of party politics and a desire for government by experts, with independence being a prized quality amongst candidates. ${ }^{15}$ However, directive responses only offer a partial understanding of how the public engaged with elections. While panellists were asked to collect election literature, they were not encouraged to offer their own reflections on this material. By contrast, the May-June 1945 directive asked for opinions on any political meetings that panellists had attended, so it is unsurprising that discussion of meetings featured prominently in replies. ${ }^{16}$

Most recently, in an important intervention, Cowan has analysed Mass Observation's survey of responses to Labour's 'Ask your Dad' slogan in 19489. The campaign sought to compare the Attlee government's record favourably with the widespread deprivation experienced under the Conservativedominated National Governments of the 1930s. Cowan highlights how those surveyed by MO did not passively consume the Labour slogan or defer to

\footnotetext{
${ }^{13}$ Fielding, 'What did "the people” want?', pp. 623-9, 637; Fielding, Thompson, and Tiratsoo, 'England arise!', pp. 212-13; Fielding's conclusions have been largely supported by Kevin Jefferys, Politics and the people: a history of British democracy since 1918 (London, 2007), pp. 77-8, 80-1, 112.

${ }^{14}$ James Hinton, '1945 and the apathy school', History Workshop Journal, 43 (1997), pp. 266-73, at pp. 267-70. Effective turnout at the 1950 and 1951 elections was likely to have been significantly higher than the official figures given they were fought on old registers, Jon Lawrence, Electing our masters: the hustings in British politics from Hogarth to Blair (Oxford, 2009), p. 138.

${ }^{15}$ Moss, Clarke, Jennings, and Stoker, 'Golden age, apathy, or stealth?', pp. 442-3, 450, 452-3.

${ }^{16}$ Will Jennings, Jonathan Moss, and Gerry Stoker, 'Changing spaces of political encounter and the rise of anti-politics: evidence from Mass Observation's General Election diaries', Political Geography, 56 (2017), pp. 13-23, at pp. 16-17.
} 
'expert' opinion; rather, they could rework it based on their own memories. A reluctance to engage with the slogan did not necessarily indicate political ignorance, in fact, it could be based on different memories of the 1930s, distrust towards party wire-pullers, and enthusiasm for political independence. ${ }^{17}$

While Mass Observation's election surveys may not offer such consistently rich insights into political memory, they do provide a unique resource amounting to several hundred interviews demonstrating how people engaged with various facets of campaigning. The following article is based on a comprehensive analysis of the surviving survey data and accompanying field notes collected in the Mass Observation election Topic Collections. An introductory section contextualizes MO's election studies by exploring debates about the appropriate use of election literature in the 1920s and 1930s. This was a period when programmatic politics grew in influence, due largely to the influence of Labour. There were, however, countervailing pressures. Politicians commonly warned against the need to avoid rash promises, a rhetorical strategy adopted most keenly by the Conservatives. The second section analyses the main constituency election questionnaires conducted by Mass Observation between 1938 and 1947. We conclude with an analysis of Mass Observation's most ambitious survey of public opinion, the 1950 General Election survey, conducted across six London constituencies. ${ }^{18}$ Only a small fraction of the survey data featured in MO's publications and much of it was only briefly summarized in file reports.

There are methodological challenges with using this material, as Mass Observation noted at the time. While MO collected huge amounts of evidence of the vernacular forms which people used to discuss politics, it paid little attention to analysing it. Surviving field notes provide few clues regarding the nature of the inter-personal dynamics of the interview process, and survey methods often appear to have been haphazard. In 1938, Harrisson and his team conducted a survey on relative interest in home and foreign affairs during the West Fulham by-election. The answers recorded by interviewers varied significantly. This was seen as largely a result of the interviewer's technique, 'as people got into the swing of the job' refusals apparently became less common. Nonetheless, MO regularly found that women were less likely to provide detailed answers than men. ${ }^{19}$ When Mass Observation conducted a survey of opinions on the Labour pamphlet Your Britain, during the Farnworth by-election the same year, some of the interviewers posed as Labour canvassers and others as Conservatives. People were more likely to give a favourable view of Your Britain if they thought they were speaking to a Conservative, while they were more likely to be sceptical about the promises made in the leaflet if they assumed they were addressing a Labour activist. ${ }^{20}$ The overall results,

\footnotetext{
${ }^{17}$ Cowan, 'The "progress of a slogan”', pp. 435-6, 452-4, 456-7.

${ }^{18}$ Mass Observation conducted further election surveys in 1951 and 1955. However, just the survey sheets survive for the former. The 1955 survey had a substantially different set of questions, none of which asked respondents directly for their views on election propaganda.

19 'Home or foreign affairs' (26 March), n.d. [1938], Topic Collection (hereafter TC), 46-2-C/1157, Fulham West, 6 Apr. 1938.

20 'Writing', p. 12, WC, 6-A/103.
} 
therefore, need to be viewed with caution. Nonetheless, they also indicate that many of those interviewed took some interest in politics and were desirous to provide the parties with feedback based on common assumptions about their main faults. Labour's opponents often attacked its supposedly rash promises, while the Conservatives were criticized for their reluctance to commit to a substantial reform programme. A more insuperable problem was ongoing distrust of the motives of Mass Observation's staff, given many of those conducting the surveys were outsiders and drawn from the higher social classes. During the anxious days of spring 1940, some of those interviewed in by-election surveys even assumed that Mass Observation's staff were connected with the British Union of Fascists (BUF), who ran several candidates until their organization was banned in May $1940 .^{21}$

Mass Observation's election surveys were crudely designed and consist largely of 'public opinion', rather than the more candid 'private opinion' revealed in overheard conversations and panel responses. The sample base also varies significantly over time. Funding from the Labour party enabled Mass Observation to undertake by-election surveys in Farnworth and West Fulham in 1938. Financial difficulties meant that similar surveys were not conducted until early 1940, when MO received further funding from the Ministry of Information. However, wartime election surveys focused chiefly on questions of war morale. Paper restrictions after May 1940 meant there was little interest in questioning the public about the documentary forms of election campaigning. Ongoing money worries led MO to confine their post-1945 election surveys to London and the surrounding region. Nonetheless, the discursive forms in which the public responded to questions about election programmes remained consistent across these elections. Those surveyed tended to discuss their judgements of the competing programmes on the basis of past records and general assessments of whether promises for future action were realistic - often to the frustration of interviewers keen to probe their views on specific policies. Sensationalist forms of campaigning, which had flourished before 1918, were to be distrusted and this accounts for most of the criticisms of 'mud slinging' recorded in these surveys.

Mass Observation's election surveys provide unique insights into the normative assumptions about how elections should be conducted, the qualities looked for in political parties, and reflections on the records of governments. ${ }^{22}$ Whereas directives rarely asked the national MO panel to reflect on the documentary forms of election literature they received, the election surveys contain an array of comments on manifestos, leaflets, and addresses. Many replies were admittedly vague and cursory, which may have been because interviewers treated this as a question of secondary importance. In Voters' choice, its brief report on the 1950 election survey, Mass Observation (keen

\footnotetext{
${ }^{21}$ Middleton and Prestwich by-election, 22 May 1940, File Report (hereafter FR) 154, p. a. The BUF was banned the day after the by-election.

${ }^{22}$ Tom Harrisson made this distinction at the time, see his article 'What is public opinion?', Political Quarterly, Aug. 1940, FR 361; James Hinton, The mass-observers: a history, 1937-1949 (Oxford, 2013), p. 187.
} 
to win business from party research departments) claimed that most people paid superficial attention to election literature and this was particularly true of doubtful voters. ${ }^{23}$ However, a reanalysis of the 1950 survey and the other election questionnaires that MO produced indicates much keener interest in the parties' competing programmes than these conclusions suggest.

By the early 1950s, the method of election surveying pioneered by Tom Harrisson, with its emphasis on qualitative, empirical research and recording colloquial speech, was dying out. Mass Observation's 1950 election survey findings were, in fact, never analysed in detail. By then, MO's work was effectively overshadowed by competing survey organizations who offered supposedly more scientific methods for understanding the voter's choice. Rival surveys focused on producing representative quantitative samples of public opinion (the results of which could be sold to newspapers and party research departments). Little attention was paid to how the public engaged with specific documentary forms of campaigning or of the language they used to articulate their attitudes towards politicians. Original sample data for these rival 1950-1 surveys does not appear to have survived. Therefore, for all their idiosyncrasies, Mass Observation's surveys ultimately provide the historian with richer insights into how the public responded to the transformation of public politics after 1918 and the growth of programmatic politics, spearheaded by Labour.

I

In the run-up to the 1924 General Election, a Labour official was quoted in The Observer outlining his plans for the contest:

Our posters are going to be in marked contrast to the trivialities of the other side and more artistic. We shall have more photography and less cartoon. The points of the [Labour] Government programme will be emphasised: the work it has done and was planning to do when it was interrupted. Our posters will include a group photograph of the Ministers...most of our literature is ready for issue, and we have no old 'dope'; it is concerned entirely with the work of the Government. ${ }^{24}$

In making this claim, the official was seeking to distance Labour from old-fashioned, sensational forms of electioneering (see Figure 1).

Over recent years, a number of efforts had been made to curb the old 'dope' and create more peaceable forms of public politics. The Representation of the People Act (RPA) 1918 included measures to prevent non-party organizations from spending money during campaigns without contributing to a candidate's expenses. These organizations had been responsible for many of the more sensationalist posters and lurid election stunts of the Edwardian years, using this loophole to enable candidates to spend well in excess of the official spending

${ }^{23}$ Mass-Observation, Voters' choice: a Mass-Observation report on the General Election of 1950 (London, 1950), p. 5.

24 'The lightning campaign', Observer, 12 Oct. 1924, p. 13. 


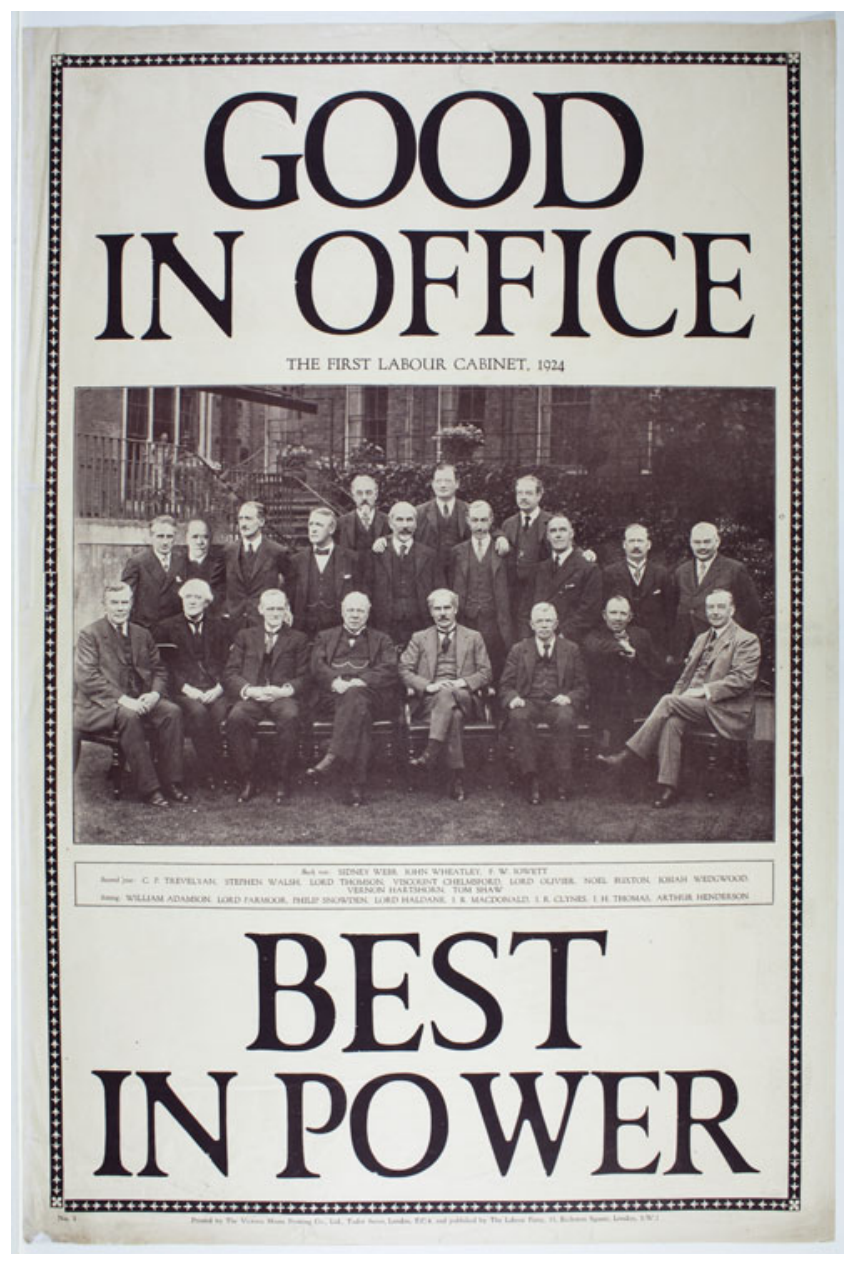

Figure I. Labour election poster, 1924. University of Bristol Special Collections: DM264I/76, Geoffrey Ford Poster Collection.

limits. ${ }^{25}$ In endorsing the clause of the bill preventing expenses by unauthorized persons, Sir George Younger, chairman of the Conservative party, claimed its purpose was to "prevent the practice of many newspapers and certain advertising agencies of booming particular candidates by contents bills, cartoons, and posting free copies of papers'. ${ }^{26}$ The RPA further sought to facilitate calmer elections by allowing candidates to send one election communication

\footnotetext{
${ }^{25}$ David Thackeray, Conservatism for the democratic age: Conservative cultures and the challenge of mass politics in early twentieth century England (Manchester, 2013), p. 117; James Thompson, “"Pictorial lies"?-posters and politics in Britain c. 1880-1914', Past \& Present, 197 (2007), pp. $177-210$.

${ }^{26}$ Parliamentary Debates, House of Commons, Fifth Series, Vol. 99, 16 Aug. 1917, col. 1425.
} 
by free post. It was assumed that this communication would include the election address - enabling candidates to provide details of their programme to all households in the constituency. ${ }^{27}$

Despite these measures, sensationalist forms of electioneering persisted. During the 1922 election, a series of Conservative leaflets used cartoons to gruesomely outline the horrors that socialism had inflicted on Russia, instructing Britons to avoid a similar fate by voting Conservative. One pamphlet showed graphic illustrations of emaciated families living a wretched existence under Soviet tyranny, with the slogan: 'This is what socialism means in Russia, keep it out of Britain by voting for the Conservative and Unionist candidate. ${ }^{28}$

The observations of the Labour official do, however, indicate that the use of such scare tactics was under challenge. From its inception, Labour had distinguished itself from its opponents by centring its election campaigns around a manifesto, which laid out a programme for reform. ${ }^{29}$ This approach stemmed, in part, from its concerns with avoiding misrepresentations of its policies from an overwhelmingly hostile national press, which often focused on figures on the extremes of the labour movement. ${ }^{30}$ By the late 1920s, Labour's appeal was centred on the promotion of a national programme and the party's candidates increasingly came to be selected with a national audience in mind. ${ }^{31}$ By offering a detailed programme for government, the relative newcomer sought to challenge anti-socialist scaremongering and present itself as a credible party of government. ${ }^{32}$

Labour's appeal to the nation, the party's 1929 election manifesto, was an important landmark in the advance of programmatic politics - not least because Labour won the largest number of seats for the first time. It included a section 'No pledges we cannot fulfil', which stated that 'we shall not deceive the people by saying that the task of National and Social Reconstruction is easy, or that it can be accomplished in a day or a year'. This was a clear rebuke to Lloyd George's well-publicized recent claim that the Liberals could deal with the unemployment crisis within a year by establishing a programme of public works. ${ }^{33}$ References to the manifesto featured prominently in speeches and print propaganda. Constituency organizations purchased nearly nine million copies of the Labour manifesto, a figure that the Conservatives came close

\footnotetext{
${ }^{27}$ Lawrence, Electing our masters, p. 110.

${ }^{28}$ Conservative Party Archive (hereafter CPA), microfiche, 0.396.220, 'This is what socialism means in Russia' (1922/102); see also 'Socialism has reduced Russia to the depths of despair' (1922/101).

${ }^{29}$ David Thackeray and Richard Toye, 'An age of promises: British election manifestos and addresses 1900-97', Twentieth Century British History, 31 (2020), pp. 1-26, at p. 9.

${ }^{30}$ For the acrimonious relationship between Labour and the capitalist press, see Laura Beers, 'Education or manipulation? Labour, democracy, and the popular press in interwar Britain', Journal of British Studies, 48 (2009), pp. 129-52, at pp. 136-42.

${ }^{31}$ Malcolm Petrie, "“Contests of vital importance": by-elections, the Labour party, and the reshaping of British radicalism, 1924-1929', Historical Journal, 60 (2017), pp. 121-48, at pp. 121, 125, 145.

${ }^{32}$ Francis Williams, Fifty years march: the rise of the Labour party (London, 1949), p. 330.

${ }^{33}$ F. W. S. Craig, ed., General Election manifestos 1900-1974 (London, 1975), p. 85.
} 


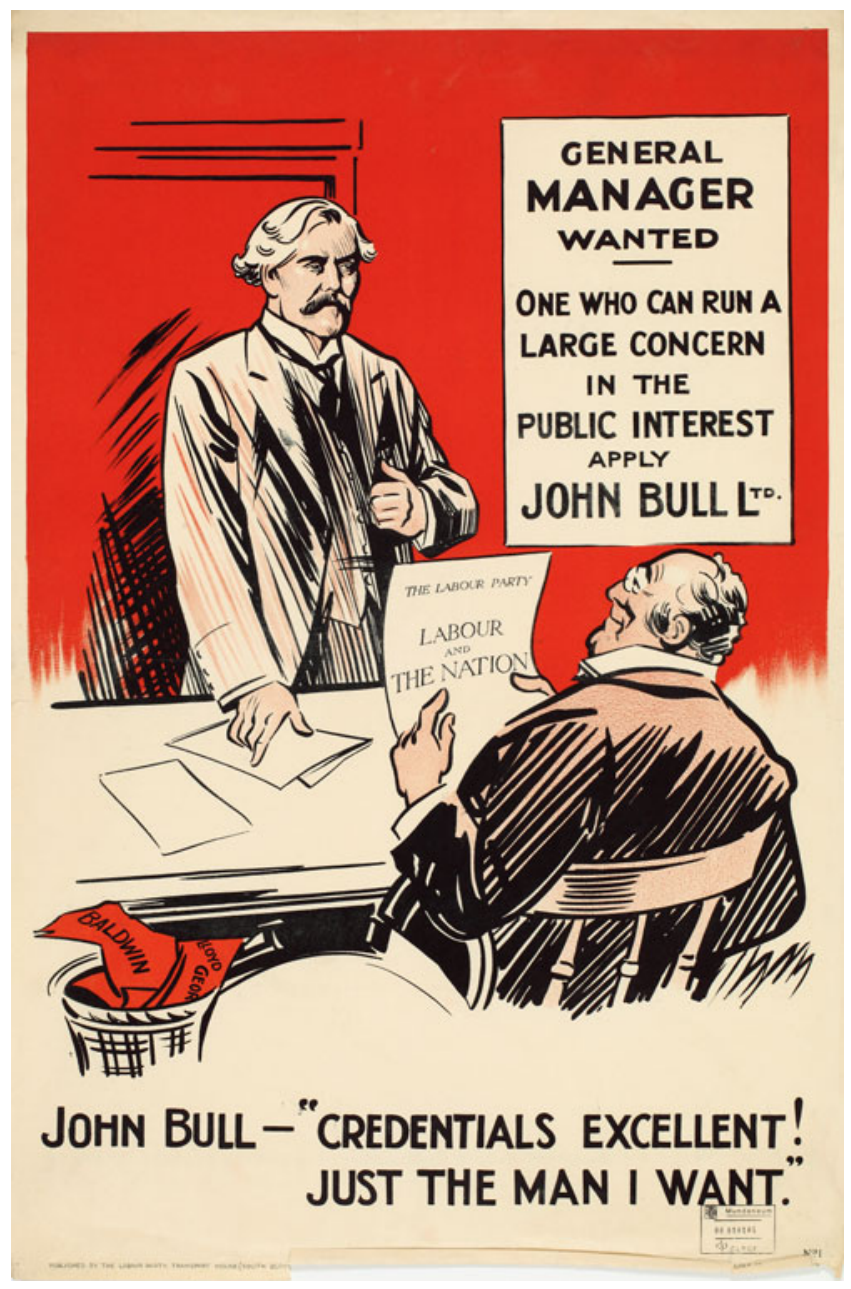

Figure 2. 'General Manager Wanted', Labour election poster, 1929, Mundaneum Collection, Mons, ARC-MUNDA-AFF-RI-I44.

to matching. ${ }^{34}$ Labour and the nation, the programme that provided the inspiration for the manifesto, featured in a poster depicting Ramsay MacDonald being interviewed by John Bull for the job of prime minister (see Figure 2). The programme acted as MacDonald's résumé, being the basis on which voters should judge his party.

\footnotetext{
${ }^{34}$ Laura Beers, Your Britain: media and the making of the Labour party (Cambridge, MA, 2010), p. 125. During the same election, the Conservatives distributed 8.3 million copies of their manifesto: John Barnes and Richard Cockett, 'The making of party policy', in Anthony Seldon and Stuart Ball, eds., Conservative century: the Conservative party since 1900 (Oxford, 1994), pp. 547-82, at p. 557.
} 
Stanley Baldwin's 1929 election address, which doubled as the Conservative manifesto, was in some ways a landmark in the party's enthusiasm for programmatic politics. However, the stress was on Baldwin's record. There were to be 'no spectacular promises for a sudden transformation of our social or industrial conditions' ${ }^{35}$ Rather, it is for the electors to judge, in the light of our past record, whether we have not faithfully redeemed the promises which we made four and a half years ago' ${ }^{36}$ Baldwin's opponents, it was claimed, could not be trusted to keep their promises. One poster, making reference to a well-known popular song, showed Labour's Ramsay MacDonald and the Liberal leader David Lloyd George blowing bubbles marked 'promises'. There were two captions: 'So pretty! Till they burst!' and 'They're for ever blowing bubbles. ${ }^{37}$

The approach failed in 1929, with Labour taking power, but was employed again thereafter. At the 1931 election, the Labour party was swept away, accused of having run away from its responsibilities when faced with an economic crisis. One poster showed an aged working (or perhaps workless) man looking up, disillusioned, from his copy of the Labour-supporting Daily Herald. The legend ran: 'No more socialist promises for me, I'm voting Conservative this time. ${ }^{38}$ The technique was repeated in 1935, when socialist promises were presented as the bait that threatened to lure a workman into a trap. $^{39}$

Labour pioneered programmatic politics then, but it had not yet got it down to a fine art. Indeed, its hastily written 1935 manifesto presented an easy target for critics. The Times noted that the first half consisted of attacks on the National Government, whereas 'the much vaunted "programme of action"' i.e. the 1934 policy document For socialism and peace - was squeezed into just one paragraph, presumably as a ploy to distract voters from its more controversial policies. ${ }^{40}$ Mass Observation started its activities at a time when programmatic politics was well established but also when there was widespread unease about the escalation of election promises. The Conservatives had achieved success in 1931 and 1935 suggesting that Labour's manifestos were untrustworthy, obscuring the more radical measures outlined in their longer programmes adopted by Conference, which they were likely to enact if given a parliamentary majority.

\footnotetext{
${ }^{35}$ Craig, ed., General Election manifestos 1900-1974, p. 70.

${ }^{36}$ Ibid., p. 80.

37 Bodleian Library POSTER 1929-28; for criticisms of Lloyd George's broken promises between 1918 and 1922, see also Bodleian Library POSTER 1929-3; 'Performances not promises: Mr. Stanley Baldwin's great election speech at Drury Lane Theatre, April 18th, 1929', CPA, leaflet 1929/192, microfiche.

${ }^{38}$ Bodleian Library POSTER 1931-2. On the theme of Labour's broken promises, see also Bodleian Library POSTER 1913-13 and the Conservative election film 'The right spirit', available at https:// player.bfi.org.uk/free/film/watch-the-right-spirit-1931-online (consulted 15 Apr. 2020).

${ }^{39}$ Bodleian Library POSTER 1935-19.

40 'The socialists' plain van', Times, 4 Nov. 1935, p. 13.
} 
In 'Swelling the Labour vote', a play for amateur dramatic groups offering an amusing take on the goings on in a municipal election campaign, Tom Harrisson drew on his experiences analysing elections in London and Lancashire in the late 1930s. Both the Conservative and Labour committee rooms are presented as taking great interest in the preparation of the election address. The Tories use the best 'cream vellum' paper while Labour agonize over the wording. In the end, the Labour address amounts to little more than a long-winded and sonorous commitment to avoid making unrealistic promises and to conscientiously serve the interests of the ward. The narrator interjects: 'This is taken from a typical election address. It is meaningless, fulsome, and no damned good. ${ }^{41}$

While Harrisson was frustrated by the standard format of much election literature, Mass Observation's early studies noted that some publications were beginning to break the mould, with Labour taking on the role of innovator. The Your Britain series of pamphlets came in for particular attention. In 1937, Labour's immediate programme had been endorsed by the party's conference; it was notable for focusing on outlining policies which a Labour government would introduce in a single term if given a parliamentary majority and offered much more concrete plans for their implementation than previous programmes. ${ }^{42}$ The first edition of Your Britain sought to present the key points from the Immediate programme in an attractive manner, making heavy use of colour and photography. This sixteen-page publication resembled the format of Picture Post, the highly popular photojournalism magazine launched the following year. Your Britain was launched in time for the autumn 1937 municipal elections and sought to demonstrate how a future Labour administration would build on its achievements in local government. Its front and back covers featured photos of new London County Council housing estates (Labour had held power at municipal level in the capital since 1934). Local party organizations purchased over 600,000 copies, far above the numbers expected of a party publication outside an election year. ${ }^{43}$

MO's Farnworth election study in January 1938 suggested that people paid far more attention to Your Britain than any of the other literature they received, with around 80 per cent of the electorate reading the pamphlet. ${ }^{44}$ Conservatives sought to present Your Britain and the Labour candidate's election address as an attempt to mislead impressionistic voters with gimmickry and wild spending plans. At one meeting a speaker asked his audience:

\footnotetext{
${ }^{41}$ TC, 46-2-A/807-9, Fulham West, 6 Apr. 1938.

${ }^{42}$ Andrew Thorpe, A history of the British Labour party (2nd edn, Basingstoke, 2000), p. 86; Williams, Fifty years march, p. 347.

${ }^{43}$ Beers, Your Britain, p. 159.

${ }^{44}$ This estimate was based on eighty-one interviews. All of those who had received Your Britain claimed to have read it, 'Writing', WC, 6-A, 102, 105. By contrast, only 31 per cent of those surveyed in the Great Lever ward of Bolton by Mass Observation during the 1937 municipal elections had read the election addresses, 'Writing', WC, 6-A/108.
} 
Have you seen the booklet issued by the Labour Party? Very interesting and appeals to the eye. But my friends, do not be gulled by the rash promises and colourful pictures depicted in that book. The Nat[ional] Gov[ernment] can offer you far greater attractions than anything portrayed in that book...The Labour Party always proposed to deal with other people's money and not their own. On the outside cover is a beautiful house that you ought to live in. Just a moment look what the Nat[ional] Gov[ernmen]t has done in respect to housing. ${ }^{45}$

In fact, Mass Observation found that most people were receptive to Your Britain. Of those who had received it, 87 per cent deemed it alright or very good; 5 per cent expressed sceptical comments, along the lines that the vision of Britain would be nice 'if it were true'. ${ }^{46}$ When prompted for their thoughts on the scenes of the London County Council housing estate on the front and back cover, most comments were favourable but some were unconvinced, with comments such as 'Look happy enough, but are they real photos?' ${ }^{47}$

Mass Observation undertook a similar survey during the West Fulham by-election in April 1938 sponsored by the Labour party, who wished to gauge reactions to the recently released Your Britain No. 2, which focused on foreign policy. MO asked 141 people to give an opinion on Labour's 'new sheets' (the election address, Your Britain, and a newspaper-style broadsheet). Rather than focusing on the appeal of particular issues, most answers offered a general comment on whether they found the party's promises convincing as a whole. Some who had read both Conservative and Labour addresses expressed a preference for the former, based on the failings of the last Labour government. These respondents also suggested that Labour's smartly presented literature sought to gull impressionable voters: (M18) 'Labour makes promises which it is impossible to carry out...Picture on the labour to catch the women... How are they going to get the money for their reforms. More unemployment in 1931. Conservatives haven't promised so much. And so may be able to carry out their promises.' (W60) 'Well illustrated which made it worth reading. [Your Britain] should make a big impression on illiterate people. Intelligent person soon pick holes in it. ${ }^{48}$ Despite these sceptical comments, Your Britain No. 2 was favourably received in Fulham overall, although Mass Observation found that significantly fewer people had read it than those surveyed in Farnworth when the first edition had been recently released. ${ }^{49}$ This relative lack of interest partly stemmed from the focus of the West Fulham campaign. Whereas it

\footnotetext{
${ }^{45}$ Report of Conservative meeting, All Saints, 18 Jan. 1938, WC, 7-D/374-5; 'Writing', WC, 6-A/ 106. Similar criticisms were made by Conservative speakers in Aberdeen, who claimed that Your Britain contained attractive pictures and striking promises but a lack of detail on how reforms would be paid for, 'The socialist policy', Aberdeen Journal, 11 Dec. 1937, p. 8.

46 'Writing', WC, 6-A/105.

${ }^{47}$ Ibid.

${ }^{48}$ TC, 46-2-C/1177, 1349, Fulham, West, 6 Apr. 1938.

${ }^{49} 46$ per cent of those interviewed claimed to have read Your Britain No. 2, 59 per cent made 'positively favourable comments', 'Writing', WC, 6-A/106; 15 per cent said they had no intention of reading it, TC, 46-2-C/1320.
} 
was widely assumed that foreign affairs would dominate the by-election, Edith Summerskill, the Labour candidate, concentrated more heavily on domestic issues in the last week, which appears to have contributed to her victory. ${ }^{50}$

Although Mass Observation made studies of subsequent by-elections, it did not attempt an election survey on the scale of the Farnworth and West Fulham operations until February 1940, when it examined two London by-elections, Southwark Central and Silvertown, the latter was the first project for which it received funding from the Ministry of Information. However, MO's efforts to gain a clearer understanding of how the public engaged with election literature during these early wartime by-elections were hampered by the sheer volume of it produced by candidates. At Southwark Central, the question that received the vaguest answers was 'Which do you think is the best circular or leaflet?' This was unsurprising given that many people had been 'swamped' with leaflets. ${ }^{51}$ In nearby Silvertown, it was estimated that the average home received around thirty pieces of literature. ${ }^{52}$

Mass Observation undertook their most ambitious wartime by-election survey at North-East Leeds in March 1940. The contest was won overwhelmingly by John Henderson (Conservative), who took 97 per cent of the vote, against a Fascist, Sydney Allen. Over 500 doorstep interviews took place and this is the earliest MO election survey where large numbers of the original questionnaires survive. ${ }^{53}$ According to the file report, most people lacked interest in the campaign: 'under half said they had read any of the [literature] with interest' with many feeling that too much was being produced. ${ }^{54}$ Nonetheless, the questionnaires offered a more ambiguous set of responses than the file report's brief conclusions imply. Interviewees were asked: 'Are you or aren't you interested in the election leaflets that are pushed through your letter-box? Do you or don't you read them.' From the responses, it is not always clear which of the questions voters were responding to, with many brief answers. Some appear to have assumed that they were being asked about the literature produced by the BUF candidate, which, combined with a widespread dislike of by-elections taking place during wartime, may explain the large numbers who expressed hostility to the leaflets. ${ }^{55}$ Typical replies include: (F50D) 'Just glanced it. I don't know why it should, because I am anti-fascist' and (F25C) 'Lots of rubbish. Who wants Fascists anyway. ${ }^{56}$ Allen's election address included various inflammatory statements such as his claim that the war

\footnotetext{
${ }^{50}$ Report on West Fulham by-election, March 1938, FR A7.

${ }^{51}$ TC, 46-3-E/2350, Southwark Central, 10 Feb. 1940; Searson, the 'Labour, anti-war' candidate printed 116,000 leaflets, including 36,000 copies of his election address, only 8,217 votes were cast in the by-election, TC, 46-E-H/2719.

${ }^{52}$ Silvertown by-election, 29 Feb. 1940, FR 39, p. 18.

${ }^{53}$ The Farnworth and Fulham by-election studies are discussed in Mass Observation, Britain by Mass-Observation (London, 1939), pp. 42, 46-9, 54-6, 64-5. They also feature heavily in the surviving drafts of the 'Politics and the non-voter' manuscript. It is likely that only material deemed useful for these book projects survived in the Mass Observation archive.

${ }^{54}$ North-East Leeds by-election, FR 59, pp. 17-18.

${ }^{55}$ Ibid., p. 4.

${ }^{56} \mathrm{TC}, 46-5-\mathrm{B} / 4036,4042$.
} 
was 'no quarrel of the British people: this is a quarrel of Jewish finance'. ${ }^{57}$ Around two-thirds of respondents who gave a definite answer claimed to have read at least one of the election leaflets (this includes several who said they were hostile to the literature or not interested)..$^{58}$

While more modest surveys were conducted at subsequent by-elections, they tended to focus more on questions of war morale rather than how people responded to election literature (although in April 1940 it was noted that small boys had made paper aeroplanes out of one of the Battersea North candidate's election addresses after they were unwisely given copies to distribute).$^{59}$ After May 1940, the torrent of by-election literature dried up as the result of a paper shortage and a need to preserve space in merchant shipping. Thereafter, candidates made a virtue of their moderate and economical output of election leaflets. ${ }^{60}$ Ultimately, the conditions of wartime, when people were at first flooded with election literature then starved of it, did not enable Mass Observation to continue the detailed analysis of party political literature which it had pioneered in its analysis of the Your Britain pamphlets.

\section{III}

Mass Observation's surveys during the 1945 General Election were confined to a detailed questionnaire in East Fulham (396 respondents) and a survey which focused on reactions to Churchill's and Attlee's first election radio broadcasts with 192 respondents drawn from various regions of London (Chelsea, Hampstead, Fulham, Harlesden, Hammersmith). These surveys provided the main basis for MO's 140-page file report on the election, which has been used to suggest that the electorate was 'dispirited' and apathetic, with many paying little attention to the campaign. ${ }^{61}$ However, a detailed analysis of Mass Observation's survey questionnaires indicates that this apparent apathy resulted from frustration at the conduct of the election rather than a broader disinterest in politics. ${ }^{62}$ In fact, the results suggest a general lack of cynicism, with widespread confidence that the next government would be able to enact significant social reforms.

While MO's election file report made reference to low morale, this largely resulted from the controversial early radio broadcasts by the party leaders. ${ }^{63}$ In particular, there was widespread hostility to Churchill's claim that Labour would have to 'fall back on some form of Gestapo' to enact its proposed reforms

\footnotetext{
${ }^{57} \mathrm{TC}, 46-5-\mathrm{D} / 4382$.

${ }^{58}$ Around two-thirds of those who gave a positive response claimed to have read at least one of the election leaflets, TC, 46-5-B, Leeds, North-East, 13 Mar. 1940.

${ }^{59} \mathrm{TC}, 46-6-\mathrm{A} / 4676$.

${ }^{60}$ Middleton and Prestwich by-election, 22 May 1940, FR 154, p. 7; Newcastle [North] by-election, 7 June 1940, FR 195, p. 13; Northampton by-election, 6 Dec. 1940, FR 552, p. 4.

${ }^{61}$ Fielding, 'What did "the people" want', p. 632.

${ }^{62}$ The BIPO similarly found widespread frustration at the conduct of the election campaign, as a result of 'mud slinging' and scare stories, Nick Clarke, Will Jennings, Jonathan Moss, and Gerry Stoker, The good politician: folk theories, political interaction, and the rise of anti-politics (Cambridge, 2018), p. 93.

${ }^{63}$ 'A report on the General Election, June-July 1945', p. 4, FR 2268.
} 
if given power. As Richard Toye notes, Labour was also not above accusing its opponents of employing Fascist methods at this time. ${ }^{64}$ These exchanges were a major reason why Mass Observation recorded so many criticisms of 'mud slinging' during the election campaign, a phenomenon which has unfairly been seen as representative of popular attitudes to party politics in the latter half of the 1940s more broadly ${ }^{65}$ Criticism of Churchill's speech stemmed from a sense that he was engaging in an outdated form of sensationalist electioneering, which masked his party's lack of an appealing programme. A panellist from Dewsbury quoted in the file report had little time for Churchill's attacks on his wartime colleagues: (F40C) 'I wouldn't call it a thoughtful or an instructive speech, but rather an old-fashioned election speech, ranting and abusive. But haven't ordinary people got a bit beyond that? Haven't they grown up since $1906 ?^{66}$ As a young Liberal MP, Churchill had benefited from the notorious 'Chinese Slavery' election cry in 1906, which caused a sensation when lurid posters appeared presenting indentured Chinese labourers working in barbaric conditions in South Africa. Further criticisms were recorded in the London survey conducted in the days following Churchill's and Attlee's opening radio broadcasts. Typical comments included: (M30C) 'On the whole a soap box speech. Mr. Churchill didn't set out the Conservative Party's aims, but gave an unjustified attack on the other partys [sic].' (M30C) 'He didn't state a definite programme. He seems to be relying on the fact that he's a great war leader. Which isn't fair. ${ }^{167}$ Over 80 per cent of those interviewed expressed hostility to the Gestapo speech or felt it more bad than good; only 12 per cent were explicitly favourable. ${ }^{68}$

While the 1945 election has retrospectively been viewed as an indicator of growing political apathy, Tom Harrisson drew quite a different conclusion at the time. Writing in Political Quarterly in September 1945, he noted a "comparative absence of cynicism' compared to previous by-elections. This, he claimed, stemmed from 'the restrained programmes' put forward by Labour and the Conservatives, 'neither indulged in wild promises'. ${ }^{69}$ Let us face the future was subsequently attacked by its critics as a 'sinister' and radical pamphlet but at the time it attracted little critical comment. ${ }^{70}$ When East Fulham voters were asked whether they thought the next government would be able to 'do just what you want' on the key issues (housing was identified overwhelmingly as the main priority of those interviewed), 60 per cent said they would or probably would. ${ }^{71}$ Although Churchill's leadership was a key attraction for

\footnotetext{
${ }^{64}$ Richard Toye, The roar of the lion: the untold story of Churchill's World War II speeches (Oxford, 2013), pp. 209-10, 220.

${ }^{65}$ FR 2268, pp. 4, 10. For the idea that Mass Observation evidence demonstrates widespread frustration with 'mud slinging' during the latter half of the 1940s, see Moss, Clarke, Jennings, and Stoker, 'Golden age, apathy, or stealth?', pp. 442, 450, 452-3.

${ }^{66}$ FR 2268, p. 14.

${ }^{67} \mathrm{TC}, 76-3-\mathrm{E} / 1923,1927$.

${ }^{68} \mathrm{TC}, 76-3-\mathrm{E} / 1900$.

${ }^{69}$ FR 2282, p. 7.

${ }^{70}$ For the supposedly sinister qualities of Let us face the future, see Quintin Hogg, The case for Conservatism (London, 1947), p. 160.

${ }^{71}$ FR 2265, 'General Election', p. 10.
} 
Conservative voters, people otherwise made their decisions on who to vote for based on perceptions of who would keep their promises. ${ }^{72}$ The East Fulham survey contained the question 'How do you feel about the election propaganda at this election?', which elicited many disapproving comments about 'dirt' and 'mud slinging'. However, the MO report was cautious about drawing conclusions from these results. Unlike the 1950 survey, there was no question that asked respondents specifically for their views on election literature - so the critical comments covered various facets of the campaign. ${ }^{73}$ In particular, many demonstrated frustration at the behaviour of national leaders or expressed hostility to the election being fought on an old register while Britain was still at war with Japan. ${ }^{74}$

A 'Postscript' to MO's General Election file report written in April 1946 concluded that the election campaign had little effect on people's voting intentions; 'they voted on the long-term reputation of their party, an impression built up over many years' ${ }^{75}$ Nonetheless, this did not mean that most people were uninterested in the party's key policies, rather than the particular circumstances of the time meant that they were already well known when the campaign started. ${ }^{76}$ Churchill's Declaration of policy to the electors made various allusions to policies, which had been outlined in his 'Four Years' Plan' broadcast of 1943, and subsequent white papers. ${ }^{77}$ Similarly, Let us face the future drew heavily on well-established Labour policies and principles, many of which had been adopted by the party before the war as part of its Immediate programme. ${ }^{78}$ In many ways, Labour's triumph in 1945 rested on their ability to make this programme appear more credible than it had been before the war.

While it has often been used as a source for exploring changing attitudes to the Attlee governments, Mass Observation's election activities after 1945 were modest in scope and confined to London and surrounding regions. They only attempted one more large-scale by-election questionnaire, at Battersea in July 1946, which demonstrated widespread hostility towards politicians on account of distrust towards both the major parties. ${ }^{79}$ Typical comments quoted in the file report included: (M35C) 'Remains to be seen...promises...they forget about it when they get in', (M60C) 'You don't get results, just as it was in the last election. ${ }^{80}$ And yet, while the report concluded that for many election literature was 'just not worth bothering about, a waste of paper', the survey results

\footnotetext{
${ }^{72}$ FR 2265, p. 12; TC, 76-2-I, 1074.

${ }^{73}$ FR 2265, pp. 16-18. The alternative wording, 'How do you feel about the way elections are run?' was used in some interviews.

74 See for example TC, 76-2-J/1096, 1097, 1114, 1126-7, 1138, 1233.

75 'Postscript 1946 - General Election and after', TC, 76-3-H, 2134. Similar claims were made in a Tom Harrisson article, which appeared in Political Quarterly in September 1945, FR 2282, p. 5.

76 'Postscript 1946'.

${ }^{77}$ Craig, ed., General Election manifestos 1900-1974, p. 115.

78 'Notes of the week', Economist, 28 Apr. 1945; 'The Labour programme', New Statesman \& Nation, 28 Apr. 1945.

79357 people were interviewed for the survey, FR 2410, p. 8.

${ }^{80}$ Ibid., pp. 8-9.
} 
suggested more equivocal results. Only 23 per cent of Labour voters and 14 per cent of Conservative voters stated that they were not interested in the election literature. The equivalent figure for non-voters was 25 per cent. ${ }^{81}$

Subsequent attempts by Mass Observation to gain sponsorship from the Conservatives and Labour to conduct research into the appeal of their national propaganda efforts had limited success. The Conservative party commissioned MO to produce a report into responses to its Industrial Charter. Launched in May 1947, the Charter was a major policy document, seeking to reconcile the Conservatives with the key economic and social reforms introduced by the Attlee government and committing the party to a mixed economy. However, MO's investigations suggested that few people were aware of the Charter. Attempts to get people to identify key policy differences between the Conservatives and Labour were also largely unsuccessful: 'less than one in ten gave any that were political (e.g. Labour believes in nationalisation) as opposed to personal (e.g. Labour doesn't keep promises)'. The report appeared dismissive of answers that focused on general discussion of promisekeeping and suggested they demonstrated a lack of political knowledge. ${ }^{82}$

A subsequent survey was conducted in 1948-9 asking people for their opinions on Labour's 'Ask your Dad' slogan, in the hope of future commissions from Transport House. It appears to have been unsuccessful in this regard. The survey indicated that most people were unfamiliar with the 'Ask your Dad' slogan or unaware of its political connotations. ${ }^{83}$ The results did at least suggest that Labour's attacks on the record of the Conservativedominated National Government of the 1930s, which had been a core feature of their 1945 campaign, were now being greeted with scepticism by many frustrated at the record of the Attlee government. ${ }^{84}$ By this time, Mass Observation had to compete for the attention of Conservative Central Office and Transport House with a number of survey organizations such as the British Institute of Public Opinion (BIPO) and Research Services Ltd. The 1950 election acted as a key test of the appeal of these competing approaches, with Mass Observation losing the battle for attention and credibility.

\section{IV}

Unlike its pre-war studies of elections in Lancashire and London, which it planned to discuss at length in the uncompleted book 'Politics and the nonvoter', or its detailed study of the 1945 election, Mass Observation's General

\footnotetext{
${ }^{81}$ Ibid., p. 8.

82 'A report on the Industrial Charter', Sept. 1947, FR 2516, pp. 8, 11. The reception of the Industrial Charter is discussed in more detail in Andrew Taylor, 'Speaking to democracy: the Conservative party and mass opinion from the 1920s to the 1950s', in Stuart Ball and Ian Holliday, eds., Mass Conservatism: the Conservatives and the public since the 1880s (London, 2002), pp. 78-99, at pp. 85-8.

${ }^{83}$ Cowan, 'The "progress of a slogan"', p. 435.

${ }^{84}$ In the Nuffield study's sample of 1945 election addresses, it was noted that c. 60 per cent of Labour candidates attacked the Conservatives' interwar record, R. B. McCallum and Alison Readman, The British General Election of 1945 (London, 1947), p. 102.
} 
Election survey of 1950 led to a publication. However, the eventual output, Voters' choice, lacked the detailed analysis to be found among the archived book drafts and file reports generated by earlier election surveys. In part, this was the result of it being a rushed publication featuring a mere twelve pages of analysis. The 1950 election survey was designed 'to sell to newspapers' and 'use as a post-election lever towards further political jobs'. ${ }^{85}$ In particular, Mass Observation hoped to win future commissions from the Labour party. Planning notes for the General Election survey suggested that Michael Young, Labour's director of research, should be contacted in case he wished to add extra questions on commission (the Conservatives established their own in-house inquiry into the campaign). ${ }^{86}$ Following completion of the Mass Observation survey, it was decided to issue a short publication to attract attention to the results. ${ }^{87}$ Labour had been returned with a slim majority of five seats, so another election was likely in the near future. Nonetheless, efforts to gain Michael Young's attention failed.

Alexandre Campsie has indicated that Mass Observation researchers played a prominent role in Labour policy work and academic sociology from the 1940s onwards. ${ }^{88}$ Michael Young was central to the development of these networks, providing a bridge between the social observation pioneered by MO, the emerging field of community studies, and the politics of the New Left. ${ }^{89}$ Despite this, Mass Observation's particular tradition of election surveying effectively died out in the early 1950s, as it struggled to find favour with the main parties' research departments. Working in co-operation with Edward Shils, a sociologist based at the London School of Economics (LSE), Young was, in fact, instrumental in setting up a rival election survey in 1950. The Greenwich survey was funded by Leonard Elmhirst, a long-time ally of Young, with whom he had worked closely during his time at Political and Economic Planning. ${ }^{90}$ Mark Abrams, the head of Research Services Ltd, who branded Mass Observation's methods as amateurish, was involved in initial discussions over the project but the contract for fieldwork eventually went to the BIPO. ${ }^{91}$ Young described these organizations in an internal party memorandum reflecting on the election results as 'the most reputable opinion survey organisations'. ${ }^{92}$

Mass Observation's 1950 election survey interviewed 651 people across six London constituencies that Labour had won from the Conservatives in

\footnotetext{
85 'Notes on 1950 election survey', Jan. 1950, TC, 76-7-B/4697.

${ }^{86}$ Ibid.

87 'Some notes on the preliminary publication of election material', n.d., TC, 76-7-B/4772.

${ }^{88}$ Alexandre Campsie, 'Mass-Observation, left intellectuals and the politics of everyday life', English Historical Review, 131 (2016), pp. 92-121, at pp. 95-6.

${ }^{89}$ Ibid., pp. 92-5, 108-10.

${ }^{90}$ Raymond M. Lee, “"The man who committed a hundred burglaries”: Mark Benney's strange and eventful sociological career', Journal of the History of Behavioral Sciences, 51 (2015), pp. 409-33, at p. 416.

${ }^{91}$ Ibid., pp. 416-18; Mark Abrams, Social surveys and social action (London, 1951), pp. 105-13.

${ }^{92}$ Michael Young, 'General Election 1950. Notes on the findings of the public opinion polls', R.D.350/ April 1950, People's History Museum, Manchester, Labour Party Archive (hereafter LPA), B/F1950/1.
} 
$19455^{93}$ The surviving archival notes suggest a rather cursory level of analysis. One employee drew up notes on a sample of 444 of the responses: 'Wide expression leaflets are no good, waste of paper, don't convince anyone', comments that were paraphrased in the published report. ${ }^{94}$ Nonetheless, the unpublished survey results offered a wide range of insights passed over in Voters' choice. Comments about 'mud slinging', which were such a feature of the 1945 survey, rarely featured in 1950-even though both parties traded accusations about their opponents' failure to keep their promises in office. ${ }^{95}$ While many respondents were critical of election literature, this was as often the result of a sense that it did not provide sufficient detail about policy or offered unrealistic promises, as the idea that it was a waste of paper. ${ }^{96}$ Typical comments included: (M42B) 'Exactly what you would expect in election leaflets - a lot of vague promises in the Labour leaflet. The Cons.[ervative] leaflet stated the case very fairly I thought', (F25C) 'Of course the Labour Party are churning out all that old stuff about unemployment in the 30s rather than considering the unemployment that will be created if they carry on with their current policies. The Conservative leaflet states the facts. ${ }^{97}$

There were significantly more favourable observations about election literature recorded in the 1950 election survey than in 1945. Others who were critical of the party programmes indicated that they had read the literature keenly, weighing it up against other sources of information. Comments included: (M40D) 'They are all quite well done - all present the reader with a good case on the surface - so they have to be carefully sifted', (M37B) 'I prefer to hear them at meetings. There are too many points missed in the manifestos \& literature', (M34C) 'Read most that's been sent. They are none of them very interesting. I've stuck to the newspapers for information about policy \& the broadcasts. ${ }^{98}$

These critical comments about campaign literature tallied with the Conservatives' in-house opinion research. Churchill's opening radio broadcast appears to have received a much more sympathetic response than the 'Gestapo' speech of 1945 with praise for his 'fair criticism' and 'no rash promises'. ${ }^{99}$ However, after the party's narrow defeat, an internal post mortem

\footnotetext{
93 'Notes on 1950 election survey', Jan. 1950, TC, 76-7-B/4697.

${ }^{94}$ Mrs Hingeley, 'Notes on No 1-444', in 'Papers relating to the 1950 General Election survey', TC, 76-7-B/4736; Mass-Observation, Voters' choice, p. 6.

${ }^{95}$ See the examples of Conservative leaflets in Churchill Archives Centre, Cambridge, Winston Churchill papers, CHUR2/123. For Labour propaganda, see H. G. Nicholas, The British General Election of 1950 (London, 1951), p. 213.

${ }^{96}$ Several comments regarding 'mud slinging' and 'waste of paper' are underlined in the archive; see for example, TC, 76-5-A (East Ham)/3056, 3119. Many of the 'waste of time' comments come from one constituency, 76-5-D, Islington East.

${ }^{97}$ TC, 76-5-B (Fulham East)/3192, 3205, 3207, see also TC, 76-5-A (East Ham)/3030, 3042. On the parties' respective promises, see also $3078,3083-4$.

${ }^{98} \mathrm{TC}, 76-5-\mathrm{C}$ (Hendon North)/3335, 3396; TC, 76-5-F (Walthamstow East)/3800; see also TC, 76-5-A/3133-4.

${ }^{99}$ Richard Toye, 'Assessing audience reactions to Winston Churchill's speeches', in Jens E. Kjeldsen, ed., Rhetorical audience studies and reception of rhetoric: exploring audiences empirically (Basingstoke, 2018), pp. 85-107, at p. 102.
} 
suggested that some Tory voters felt that the manifesto of that year 'was not sufficiently explicit and that some of the wording appeared to be deliberately vague'. It followed that future policy statements should be devised with attention to those 'mistrustful and cynical' electors who were on the alert 'for sentences which they can construe as being intentionally vague'. The document urged the use of specific formulations such as 'We can and will...' and 'We are determined to...' instead of 'We want to see...', 'We would like to...', etc. ${ }^{100}$

The Greenwich election study, organized by Mark Benney and a team at the LSE, ultimately attracted more attention than Mass Observation's work, providing the basis for a number of constituency-level election studies in the 1950s. ${ }^{101}$ Benney's team drew on methods pioneered by MO but sought to offer a more rigorous account of the effects of the campaign. Students recorded audience reactions at meetings, the public display of election posters, and the distribution of party literature-methods established by Tom Harrisson. ${ }^{102}$ However, whereas MO relied on haphazard doorstep interviews and a self-selecting volunteer panel, the Greenwich survey constructed a panel of 900 people drawn at random from the electoral register. The Greenwich panel members were interviewed up to three times by the BIPO, showing how opinions changed during the campaign and in its aftermath, an approach pioneered in the 'Columbia' study of Elmira, New York, during the 1948 US Presidential Election. ${ }^{103}$ Michael Young discussed the Greenwich survey at length in the Labour's Research Department's analysis of opinion polling, along with the wider work of the BIPO and Research Services Ltd, who were all praised for their thorough attention to creating a representative sample base. The rival work of Mass Observation was overlooked. ${ }^{104}$

The authors of the Greenwich study stressed that most of the public was politically uninformed and took little interest in elections. Almost half of their respondents claimed they were 'not very interested' in politics, around a third said they were 'moderately interested', only 10 per cent stated they were 'very interested'. ${ }^{105}$ Some of the evidence which the Greenwich survey collected does not seem to accord with this claim, for example, one in five displayed window-cards in favour of a particular candidate in the days leading up

\footnotetext{
${ }^{100}$ Public Opinion Research Department, 'Confidential supplement to Public Opinion Summary No. 14', 5 Mar. 1950, Bodleian Library, Oxford, CPA, CCO 4/3/249; for the wider activities of the department, see Andrew Taylor, “"The record of the 1950s is irrelevant": the Conservative party, electoral strategy and opinion research, 1945-64', Contemporary British History, 17 (2003), pp. 81-110, at pp. 83-7.

${ }^{101}$ Mark Benney, A. P. Gray, and R. H. Pear, How people vote: a study of electoral behaviour in Greenwich (London, 1956); R. S. Milne and H. C. Mackenzie, Straight fight: a study of voting behaviour in the constituency of Bristol North-East at the General Election of 1951 (London, 1954); R. S. Milne and H. C. Mackenzie, Marginal seat 1955: a study of voting behaviour in the constituency of Bristol North-East at the General Election of 1955 (London, 1958).

${ }^{102}$ William L. Miller, 'Electoral systems, elections and public opinion', in Brian Barry, Archie Brown, and Jack Hayward, eds., The British study of politics in the twentieth century (Oxford, 1999), pp. 223-56, at p. 237.

103 Lee, “"The man who committed a hundred burglaries"', p. 417.

104 Young, 'General Election 1950. Notes on the findings of the public opinion polls'.

105 Benney, Gray, and Pear, How people vote, pp. 23-5, 125.
} 
to the poll. Moreover, little sense was given of the means by which people selfdefined their levels of interest in politics. ${ }^{106}$ Regardless of how credible its claims about the public's interest in politics appear in retrospect, this early example of 'electoral sociology' was a trailblazer, doing much to shape understandings of how elections operated in the 1950s and beyond. This was an approach which linked voting behaviour to class identity, downplaying the importance of the documentary forms of campaigning in shaping voting behaviour. ${ }^{107}$

\section{V}

British politics underwent a dramatic series of upheavals between 1937 and 1950 but the ways in which people discussed why they voted for a particular party, or decided not to vote at all, remained largely constant. Mass Observation's election surveys indicate that people judged parties largely on valence issues, assessing whether parties had a credible programme and had kept their past promises. Sensational appeals or 'mud slinging' were to be distrusted, and were widely seen as a means of hiding the deficiencies of the candidate's programme. If election observers in the 1940s recorded that many people were distrustful of politicians, this should come as no surprise, as the broken promises of the past had long been used to attack opponents. The failures of the Lloyd George government, the Labour administration of 1929-31, and the 'Guilty Men' of the Hungry Thirties were a staple feature of electioneering long after the leaders of those administrations had fallen from office. ${ }^{108}$

After 1918, many commentators expressed concerns about the apparent apathy of much of the new electorate. Mass Observation found that many were unaware of key policy initiatives such as the Industrial Charter and expressed frustrations at both the record of the National Government of 1931-45 and Attlee's Labour government which followed it. Nonetheless, we should not confuse anger at the failings of the governing parties and their opponents, or hostility to particular forms of campaigning, with indifference to politics. This was an age in which programmatic politics flourished. Election manifestos grew in importance after 1918 given that parties were increasingly expected to lay out their plans for government in detail. Hundreds of thousands of copies of manifestos were distributed. ${ }^{109}$ The

\footnotetext{
${ }^{106}$ Ibid., p. 89.

${ }^{107}$ For a critique of the BIPO's methodology, see Mark Roodhouse, “'Fish-and-chip intelligence”: Henry Durant and the British Institute of Public Opinion, 1936-63', Twentieth Century British History, 24 (2013), pp. 224-48, at pp. 226, 235-43. On the influence of electoral sociology in the 1950s and early 1960s, see David Thackeray and Richard Toye, Age of promises: electoral pledges in twentieth century Britain (Oxford, 2021), pp. 10-12; Laura Beers, 'Whose opinion? Changing attitudes towards opinion polling in British politics, 1937-1964', Twentieth Century British History, 17 (2006), pp. 177-205, at pp. 191ff, 197, 199-203; Taylor, “'The record of the 1950s is irrelevant”', pp. 81-92.

${ }^{108}$ Clare Griffiths, 'Broken promises and the remaking of political trust: debating reconstruction in Britain during the Second World War', in David Thackeray and Richard Toye, eds., Electoral pledges in Britain since 1918: the politics of promises (Basingstoke, 2020), pp. 95-115.

${ }^{109}$ In spite of problems caused when a government printing order supervened, nearly 1.3 million copies of Let us face the future were distributed, 'General Election, July, 1945: report on
} 
evidence collected by Mass Observation suggests that many people weighed the claims in the competing manifestos carefully, either by reading the original texts or by following coverage of them on the radio or in the press.

We should be cautious in using Mass Observation's election surveys to explain the changing fortunes of the main political parties. After 1945, these surveys were confined to London and the surrounding region. However, what seems most striking in reading through these surveys is how unremarkable Let us face the future appeared in 1945, certainly compared to the attacks that were made on the broadly similar programme outlined in Your Britain in 1937. These conclusions support Laura Beers's argument that Labour's triumph owed much to its ability to use literature to present its programme as attractive and credible. ${ }^{110} \mathrm{MO}$ had found that Your Britain appealed to many voters in Farnworth and Fulham in 1938, suggesting that Labour's triumph in 1945 was built on the roots of its pre-war work. Labour also undoubtedly benefited from hostility to the National Government's record after 1940 and widespread enthusiasm for social reform. ${ }^{111}$ It was to be a fragile triumph. Both the "Ask your Dad' survey and the MO 1950 General Election survey indicated a widespread sense that Labour had betrayed its mandate and was relying on worn-out tales of the miseries of the 1930s rather than offering an appealing programme for the future. But if Labour struggled to hold onto power, it had still managed to change the rules of the game, as its rivals felt obliged to centre their campaigning around a detailed programme for change. ${ }^{112}$

By the early 1950s, Mass Observation's rivals were producing election studies, focused on quantitative research and opinion polling, which attracted greater attention from party research departments and the wider public. These studies tended to stress popular disengagement from politics and emphasized the role of class in determining voting behaviour. ${ }^{113}$ This approach was echoed in contemporary Nuffield studies. In 1951, David Butler, drawing on the results of recent election surveys, argued that few people took an interest in campaign literature, with probably no more than 5 per cent of people reading the party manifestos. ${ }^{114}$ The evidence collected in Mass Observation's election surveys does not support such conclusions. From the late 1930s onwards, Tom Harrisson had sought to demonstrate that the apparent apathy of much of the electorate was the result of the main parties' failure to present their policies in an appealing manner. There were, however, signs that parties were making strides to address this problem, as indicated by the success of the Your Britain pamphlets. The large print runs of manifestos, and the attention

campaign publicity services', 23 July 1945, 1945 election file, LPA. Labour printed 920,000 copies of its 1950 manifesto, 'General Election campaign: head office service', 22 Mar. 1950, B/F1950/1, LPA.

${ }^{110}$ Laura Beers, 'Labour's Britain, fight for it now!', Historical Journal, 52 (2009), pp. 667-95.

${ }^{111}$ Ross McKibbin, Parties and people: England 1914-1951 (Oxford, 2010), pp. 130, 138-9.

${ }^{112}$ For a more detailed discussion of this point, see Thackeray and Toye, 'An age of promises', pp. 3, 10, 20-1.

${ }^{113}$ Mark Benney and Phyllis Geiss, 'Social class and politics in Greenwich', British Journal of Sociology, 1 (1950), pp. 310-27; Samuel J. Eldersveld, 'British polls and the 1950 General Election', Public Opinion Quarterly, 15 (1951), pp. 115-32, at pp. 127-8.

${ }^{114}$ D. E. Butler, The British General Election of 1951 (London, 1952), pp. 3-4, 52. 
lavished on them in campaigning, suggest that Butler underestimated their significance (even if most people did not read them in their original form). As Mass Observation's surveys indicate, much of the public took an interest in weighing up the competing programmes of the parties. The broken promises of the past may have made them wary about pledges for future action but this was no age of apathy.

Acknowledgements. Parts of this article draw on research conducted with Richard Toye for the Leverhulme 'Age of Promises' project. I am grateful to Jon Lawrence, Richard Toye, and the editors and anonymous referees for their helpful comments on earlier versions of this article. All archival references are to Mass Observation Online unless specified.

Funding Statement. This research is supported by a Leverhulme Trust grant (2017-176).

Cite this article: Thackeray D (2022). Mass Observation, Apathy, and Electoral Politics in England, 1937-1950. The Historical Journal 65, 750-773. https://doi.org/10.1017/S0018246X21000170 